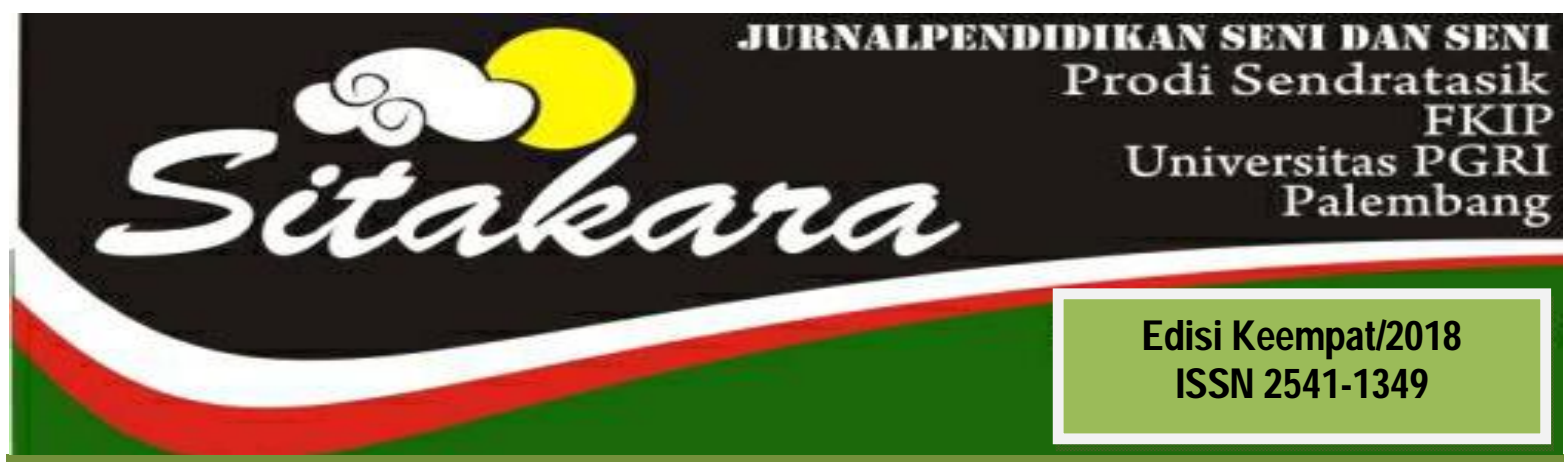

Objektifitas Imajinatif Dalam Pertunjukan Teater

Mohammad A rfani

Makna Estetis Dalam Simbol Tatto

Novdaly Fillamenta

Desain A tas (Air D esign) D alam Dimensi Estetik Pertunjukan Karya Tari

Efita Elvandari

Pengaruh M etode D emonstrasi D alam Pembelajaran Tari Burung Bermain

Pada Kegiatan Ekstrakurikuler D i SM P N egeri 36 Palembang

Ria Moulina A driamul

Gerak: Perjalanan D ari M otif Ke Komposisi Tari

Rully Rochayati

Sastra Lisan Dalam Kesenian Saluang D endang Sumatera Barat

Nofroza Yelli

Rangsang A udio Sebagai M otivasi Pada Penciptaan Karya

Tari Tunggu Tubang Dalam Pembelajaran Koreografi di Universitas

PG RI Palembang

Treny Hera

M otif Bungo Pacik Pada Tenunan Songket Palembang

Mainur

Konsep Kreatifitas Wallas D alam Proses Penciptaan Tari Tepak Keraton

Nurdin

A nalisis Bentuk Gerak Tari Turak Di Sanggar Studio Lingga

Kota Lubuklinggau

Sisca Fitriani

Bentuk Figur Tokoh Wayang Kulit Palembang

Robert Budi Laksana 


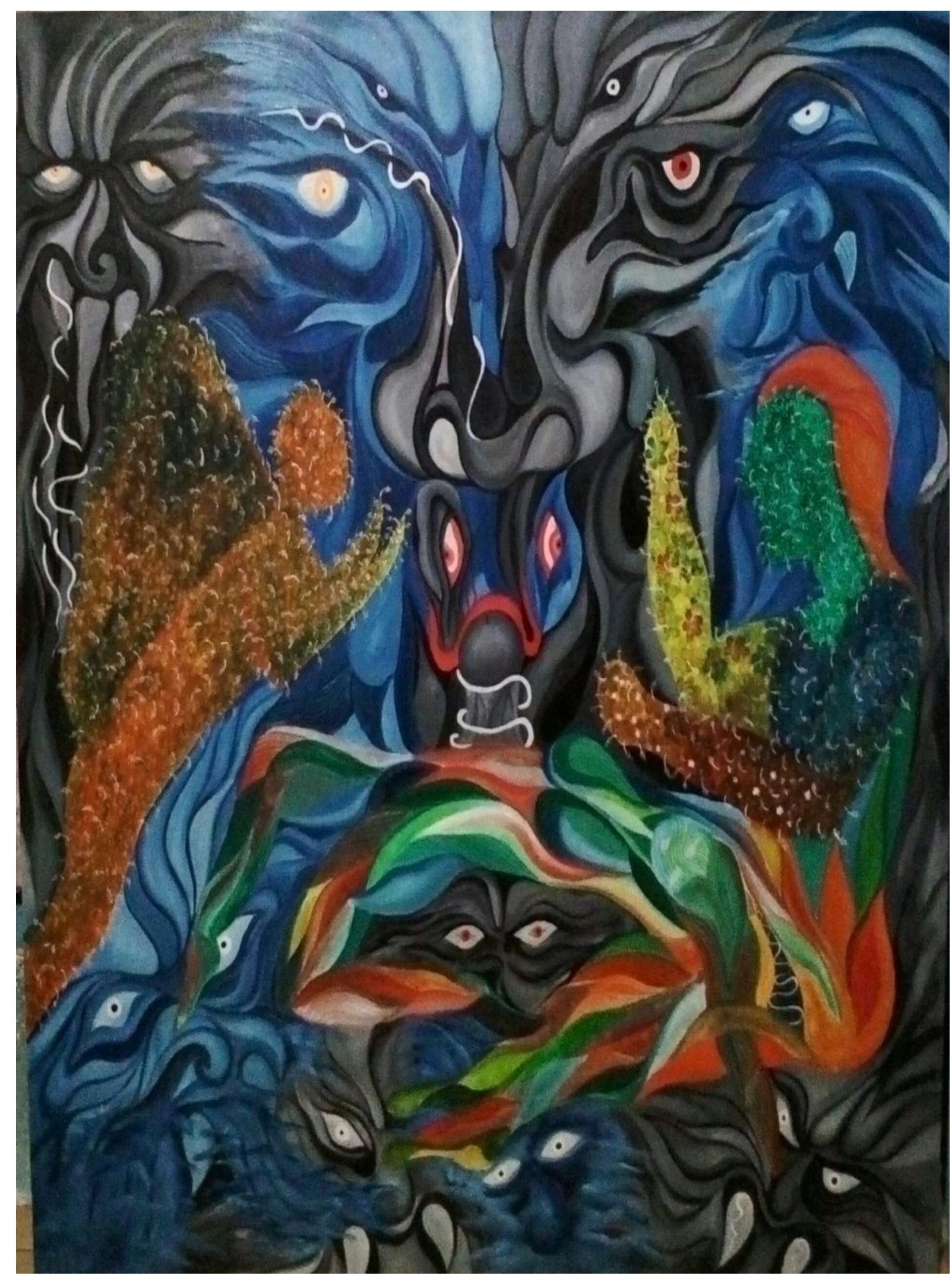




\section{SITAKARA}

\section{JURNAL PENDIDIKAN SENI DAN SENI BUDAYA}

Edisi 4, Februari 2018

\section{DEWAN REDAKSI}

1. PenanggungJawab

2. KetuaDewan Redaksi

3. WakilDewanRedaksi

4. Sekretaris

5. PenyuntingPelaksana

6. Penyunting Ahli

7. Setting
:

: Dra. Andinasari, M.M., M.Pd.

: RullyRochayati, M.Sn

: Nofroza Yelli, M.Sn

: Treny Hera, S.Pd., M.Sn

: 1. Efita Elvandari, M.Sn

2. Arfani, S.Pd., M.Sn

: 1. Prof. Dr. Triyono Bramantyo, P.Hd (ISI Yogyakarta)

2. Dr. DessyWardiah, M.Pd (UPGRI)

3. Dr. Slamet, M.Hum (ISI Surakarta)

4. Yayan Hariyansyah, M.Sn (UIGM)

: 1. Mainur, S.Pd.,M.Sn

2. I Komang Kerta Yana, S.Si

\section{AlamatRedaksi}

Program StudiPendidikanSendratasik JurusanPendidikanKesenian FKIP Universitas PGRI Palembang Jl. A. YaniLorongGotongRoyong 9/10 Ulu Palembang Telp. 0711-510043 Fax. 0711-514782 E-mail: jurnalsitakarasendratasik@yahoo.com 


\section{DAFTAR ISI}

Objektifitas Imajinatif D alam Pertunjukan Teater

M ohammad A rfani

Makna Estetis D alam Simbol Tatto

Novdaly Fillamenta

D esain A tas (Air D esign) D alam D imensi Estetik Pertunjukan Karya Tari

Efita Elvandari

Pengaruh M etode D emonstrasi D alam Pembelajaran Tari Burung Bermain 25 Pada Kegiatan Ekstrakurikuler Di SM P N egeri 36 Palembang

Ria M oulina Adriamul

G erak: Perjalanan D ari M otif Ke Komposisi Tari

Rully Rochayati

SastraL isanD al amK esenianSaluangD endang Sumatera Barat

N ofroza Yelli

Rangsang Audio Sebagai M otivasi Pada Penciptaan Karya

Tari Tunggu Tubang Dalam Pembelajaran Koreografi di Universitas

PG RI Palembang

Treny Hera

Motif Bungo Pacik Pada Tenunan Songket Palembang

Mainur

Konsep K reatifitas Wallas D alam Proses Penciptaan Tari Tepak Keraton N urdin

Analisis Bentuk G erak Tari Turak Di Sanggar Studio Lingga

Kota Lubuklinggau

Sisca Fitriani

BentukFigurT okohWayangKulit Palembang 


\title{
PENGARUH METODE DEMONSTRASI DALAM PEMBELAJARAN TARI BURUNG BERMAIN PADA KEGIATAN EKSTRAKURIKULER DI SMP NEGERI 36 PALEMBANG
}

\author{
Oleh: \\ Ria Moulina Adriamul \\ (Guru Seni Budaya SMP Negeri 36 Palembang)
}

\begin{abstract}
ABSTRAK
Salah satu penyebab rendahnya hasil belajar siswa dalam pembelajaran tari adalah kurang tepatnya penggunaan metode dalam proses kegiatan belajar mengajar, oleh karena itu dibutuhkan satu cara atau solusi untuk meningkatkan hasil belajar siswa. Salah satu cara yaitu dengan menerapkan metode demonstrasi dalam kegiatan pembelajaran tari. Metode demonstrasi diharapkan memiliki pengaruh dan hasil yang baik bagi siswa. Masalah dalam penelitian ini adalah Apakah ada pengaruh metode Demonstrasi dalam pembelajaran tari Burung Bermain pada kegiatan ekstrakurikuler di SMP Negeri 36 Palembang. Tujuan penelitian ini adalah untuk mengetahui adanya pengaruh metode Demonstrasi dalam pembelajaran tari Burung Bermain pada kegiatan ekstrakurikuler di SMP Negeri 36 Palembang. Metode yang digunakan adalah metode eksperimen dengan menggunakan desain penelitian Pre-Experimental Designs yaitu One-Group PretestPosttest Designs. Sampel dalam penelitian ini adalah seluruh siswa kelas VII, VIII, dan IX yang mengikuti kegiatan ekstrakurikuler sebagai kelas eksperimen (tanpa kelas pembanding) yaitu berjumlah 30 siswa. Teknik analisis data menggunakan uji normalitas data dan uji-t.
\end{abstract}

\section{Kata Kunci: Metode Demonstrasi, Tari Burung Bermain}

\section{A. PENDAHULUAN}

Pendidikan merupakan topik yang menarik dan senantiasa aktual untuk dibicarakan, tetapi sekaligus merupakan persoalan yang rumit dan terkesan tidak pernah dapat diselesaikan secara tuntas. Hal itu dapat dimaklumi, sebab terdapat begitu banyak unsur yang harus diperhitungkan dan berbagai aspek yang bisa dipakai untuk pertimbangan dalam pendidikan. Belum lagi persoalan perubahan zaman yang mesti dihadapi, baik oleh setiap upaya pendidikan maupun perundang-undangan dan caracara pengaturan pendidikan yang ditetapkan oleh penguasa negara atau masyarakat. Jadi, di satu pihak sulit atau bahkan mustahil untuk memberi satu gambaran utuh mengenai pendidikan yang bisa memberikan jawaban memuaskan bagi berbagai pihak, sulit juga merealisasikan gagasan pendidikan itu karena faktor kekuasaan politik di luar 
dunia pendidikan yang mengatur masyarakat ( Sudiarja, 2014 : 5).

Pendidikan dapat dipandang dari sudut masyarakat dan kebudayaan. Dari sudut ini, pendidikan berperan untuk memperkenalkan, melestarikan, mengelola, memilih, dan mengembangkan unsur-unsur kebudayaan nasional. Peran itu harus dilakukan oleh pemimpin negara, para pendidik, dan tokoh masyarakat ( Nengah, 2014 : 22).

Pendidikan adalah suatu sistem, maka inovasi pendidikan mencakup halhal berhubungan dengan komponen sistem pendidikan, baik sistem dalam arti sekolah, perguruan tinggi atau lembaga pendidikan yang lain, maupun sistem dalam arti yang luas misalnya sistem pendidikan nasional (Sa'ud, 2012:8).

Tari merupakan salah satu cabang seni yang berkembang di Indonesia. Tari tercipta sebagai hasil budaya individu yang menggunakan daya pikir untuk menciptakan gerak-gerak ritmik yang tersusun sedemikian rupa dengan jiwa seni yang tinggi. Diiringi dengan iringan musik yang tepat dengan gerak-gerak yang diciptakan kemudian menjadi sebuah tari. Tari yang sudah tercipta kemudian diperkenalkan kepada orang banyak dalam bentuk pertunjukan seni, dan dapat berkembang ketika dilestarikan, diminati, dan dijaga oleh setiap individu (Kamila, 2015:11).

Tari merupakan bagian integral dari kehidupan budaya manusia, karena tari telah ada dan hidup sejak zaman Prasejarah. Tari dengan kehidupannya bersama dengan kehidupan manusia itu memiliki kekuatan daya hidup yang mampu menjadikan manusia dapat bertahan dan mengembangkan dirinya (Wahyudiyanto, 2008:2-3).

Menari tidak hanya dituntut untuk memiliki kemampuan pribadi yang baik, tetapi juga kemampuan melakukan kerja sama dengan teman. Menari juga dituntut untuk saling menghormati, menghargai, santun, serta peduli dengan lingkungan. Saling berbagi pengalaman dan kemampuan dengan teman merupakan salah satu kunci keberhasilan meragakan tari. Penghayatan makna tari juga mengajarkan kita untuk rendah hati, tidak sombong, serta mensyukuri atas segala pemberian Tuhan. (Kemendikbud, 2014:71)

Berdasarkan observasi awal peneliti dalam pembelajaran pada kegiatan ekstrakurikuler yang sudah diterapkan guru seni budaya selama ini di SMP N 36 Palembang adalah bahwasanya 
pembelajaran yang selama ini berlangsung cukup baik. Siswa memiliki keaktifan yang cukup baik dalam pembelajaran tari serta memiliki cukup banyak ketertarikan dalam pembelajaran menari. Disekolah siswa bukan hanya mendapatkan pelajaran tentang tari saja, tetapi ada satu kegiatan atau organisasi yang memfokuskan siswa-siswa yang berminat dan ingin ikut serta dalam belajar lebih tentang tari. Organisasi yang dimaksud adalah kegiatan ekstrakurikuler tari diluar jam pelajaran.

Menurut SK Dirjen Dikdasmen Nomor 226/C/Kep/O/1992 Kegiatan ekstrakurikuler adalah kegiatan di luar jam pelajaran biasa dan pada waktu libur sekolah yang dilakukan baik di sekolah ataupun di luar sekolah, dengan tujuan untuk memperdalam dan memperluas pengetahuan siswa, mengenai hubungan antara berbagai pelajaran, menyalurkan bakat dan minat serta melengkapi upaya pembinaan seutuhnya.

Ekstrakurikuler yang sudah diterapkan selama ini di SMP N 36 Palembang berlangsung dengan menggunakan metode kerja kelompok, dimana siswa dibentuk menjadi beberapa tim guna untuk menjalin kerja sama yang baik dalam proses kegiatan menari. Namun, terkadang guru mempertunjukkan video tari ke siswa melalui laptop dengan menggunakan infokus dan ditonton bersama-sama kemudian dipraktikkan bersama tim yang telah dibentuk.

Berdasarkan fenomena yang telah dikemukakan, peneliti tertarik untuk menerapkan sebuah metode demonstrasi yang bertujuan untuk memberikan suasana baru dalam proses pembelajaran pada ekstrakurikuler tari di SMP N 36 Palembang. Sekaligus sebagai pengenalan metode baru yang selama ini belum pernah diterapkan di SMP N 36 Palembang. Metode tersebut adalah metode demonstrasi.

Metode demonstrasi adalah cara penyajian pelajaran dengan meragakan atau mempertunjukkan kepada siswa suatu proses, situasi, atau benda tertentu yang sedang dipelajari, baik sebenarnya ataupun tiruan, yang sering disertai dengan penjelasan lisan (Djamarah dan Zain, 2010:90-91).

Metode ini mudah dilakukan karena metode ini menempatkan guru sebagai figur sekaligus contoh ataupun mencontohkan dalam proses pembelajaran di kelas. Siswa menjadi pendengar sekaligus pengikut yang diperintahkan guru dan juga siswa melihat peristiwa yang terjadi. Dengan 
penggunaan metode demonstrasi diharapkan siswa akan mendapatkan suasana pembelajaran yang lain pada kegiatan ekstrakurikuler, sehingga siswa akan lebih aktif dan termotivasi dalam mengikuti kegiatan ekstrakurikuler.

Berdasarkan uraian tersebut maka penulis tertarik untuk melakukan penelitian dengan judul : "Pengaruh Metode Demonstrasi dalam pembelajaran Tari Burung Bermain pada kegiatan ekstrakurikuler Di SMP Negeri 36 Palembang Tahun ajaran 2016/2017“"

\section{B. METODE PENELITIAN}

Dalam penelitian ini, peneliti menggunakan Pre-Experimental Design yaitu One-Group Pretest-Posttest Design. Menurut Sugiyono (2011:74), Pre-Experimental Designs belum merupakan eksperimen sungguhsungguh, karena masih terdapat variabel luar yang ikut berpengaruh terhadap terbentuknya variabel dependen. OneGroup Pretest-Posttest Designs merupakan desain yang terdapat Pretest sebelum diberi perlakuan. Alasan peneliti memilih Pre-Experimental Design karena dapat melihat perbandingan antara nilai sebelum dilakukan pretest dan nilai sesudah dilakukan posttest, agar peneliti dapat mengetahui pengaruh metode demonstrasi yang digunakan. Dengan demikian perlakuan dapat diketahui lebih akurat, karena dapat membandingkan dengan keadaan sebelum diberi perlakuan.

Desain ini dapat digambarkan sebagai berikut:

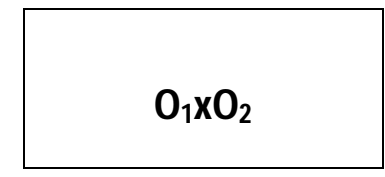

Keterangan:

$\mathrm{O}_{1}$ : nilai Pretest (sebelum diberi perlakuan)

$\mathrm{x}$ : Perlakuan

$\mathrm{O}_{2}$ : nilai Posttest (sesudah diberi perlakuan)

Dalam penelitian ini hanya ada satu kelompok sampel yang menjadi kelas eksperimen yang dilaksanakan tanpa ada kelas pembanding (kelas kontrol), dimana penelitian bertujuan untuk menerapkan suatu tindakan atau perlakuan agar hasilnya lebih optimal.

\section{PEMBAHASAN}

Sebelum penelitian dilaksanakan, peneliti terlebih dahulu mengadakan pertemuan dengan wakil kepala SMP Negeri 36 Palembang dan guru bidang 
studi seni budaya yang mengajar siswa dalam kegiatan ekstrakurikuler pada hari Kamis tanggal 30 Maret 2017. Dimana dalam pertemuan tersebut peneliti sekaligus menyerahkan surat izin penelitian dari Departemen Pendidikan Nasional Depdiknas Palembang.

Setelah menerima surat tersebut, wakil kepala SMP Negeri 36 Palembang menyambut baik maksud peneliti dan memberikan izin pelaksanaan penelitian. Selanjutnya SMP Negeri 36 Palembang menyerahkan sepenuhnya kepada peneliti dan guru bidang studi seni budaya yang telah ditunjuk untuk membicarakan rencana selanjutnya. Pada kesempatan itulah peneliti bersama guru seni budaya berdiskusi mengenai rencana kegiatan penelitian yang akan dilakukan dan menyepakati data sumber dalam kegiatan ekstrakurikuler tari di SMP Negeri 36 Palembang. Waktu pelaksanaannya adalah hari Kamis, jam 15:00 dalam kegiatan ekstrakurikuler tari.

\section{Pertemuan Pertama}

Hari Kamis, 30 Maret 2017 pukul 15:05 peneliti menyiapkan audiovisual laptop dan infokus terkait pembelajaran tari Burung Bermain. Selanjutnya peneliti memberikan tes unjuk kerja dengan memperlihatkan video tari Burung
Bermain kepada siswa dari awal sampai akhir. Setelah mereka melihat video tari, siswa memperagakan dari contoh gerak tari di video yang telah dilihat melalui laptop. Pada tes akhir pembelajaran peneliti memperoleh skor/nilai berupa angka-angka yang dicapai masingmasing siswa. Pada tes awal sebelum menerapkan metode demonstrasi (pretest).

\section{Pertemuan Kedua}

Hari Kamis, 06 April 2017 peneliti menerapkan metode demonstrasi, dimana peneliti memberikan contoh gerak tari Burung Bermain di depan siswa. Satu persatu siswa memperagakan tari Burung Bermain dengan menggunakan hitungan dan ketukan sesuai irama musik.

\section{Pertemuan Ketiga}

Hari Kamis, 13 April 2017 peneliti mengevaluasi siswa pada tes unjuk kerja terakhir (Posttest). Pada tes akhir pembelajaran peneliti memperoleh skor nilai akhir berupa angka-angka yang dicapai masing-masing siswa.

\section{Hasil dan Analisis Data Tes}

Tes ini dilakukan untuk mengetahui hasil belajar siswa yang diambil nilai tes 
unjuk kerja yaitu Pretest dan Posttest dalam kegiatan ekstrakurikuler yang diajarkan dengan menggunakan metode demonstrasi.

\section{Analisis Data Pretest Pembelajaran}

Tari Burung Bermain
Hasil Pretest yang diperoleh siswa alam pembelajaran tari Burung Bermain sebelum diterapkan metode demonstrasi, dapat dilihat pada tabel distribusi Frekuensi berikut ini:

TABEL DISTRIBUSI FREKUENSI PRETEST

\begin{tabular}{|c|c|c|c|c|c|}
\hline Interval & $f_{\mathrm{i}}$ & $\mathbf{x}_{\mathrm{i}}$ & $\mathbf{x i}^{\mathbf{2}}$ & $f_{\mathrm{i}} \mathbf{x}_{\mathrm{i}}$ & $f_{\mathrm{i}} \mathbf{x}^{2}$ \\
\hline $50-54$ & 4 & 52 & 2.704 & 208 & 10.816 \\
\hline $55-59$ & 5 & 57 & 3.249 & 285 & 16.245 \\
\hline $60-64$ & 9 & 62 & 3.844 & 558 & 34.596 \\
\hline $65-69$ & 8 & 67 & 4.489 & 536 & 35.912 \\
\hline $70-74$ & 0 & 72 & 5.184 & 0 & 0 \\
\hline $75-79$ & 3 & 77 & 5.929 & 0 & 0 \\
\hline $80-84$ & 1 & 82 & 6.724 & 82 & 6.724 \\
\hline & 30 & 469 & 32.123 & 1.669 & 104.293 \\
\hline
\end{tabular}

e. Mencari rata-rata nilai pretest $(\bar{X}$ )

$$
\bar{x}=\frac{\sum f_{i} x_{i}}{\sum f_{i}}
$$

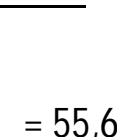

$$
\begin{aligned}
\text { Mo } & =b+P(-) \\
& =59,5+5(-) \\
& =59,5+5(-) \\
& =59,5+5(1) \\
& =64,5
\end{aligned}
$$

f. Mencari Modus Nilai Pretest (Mo)

$$
\begin{aligned}
& \left(b=60-0,5=59,5 ; P=5, ; b_{1}=9-5=\quad\right. \text { g. Mencari Simpangan Baku } \\
& \left.4 ; b_{2}=9-8=1\right)
\end{aligned}
$$




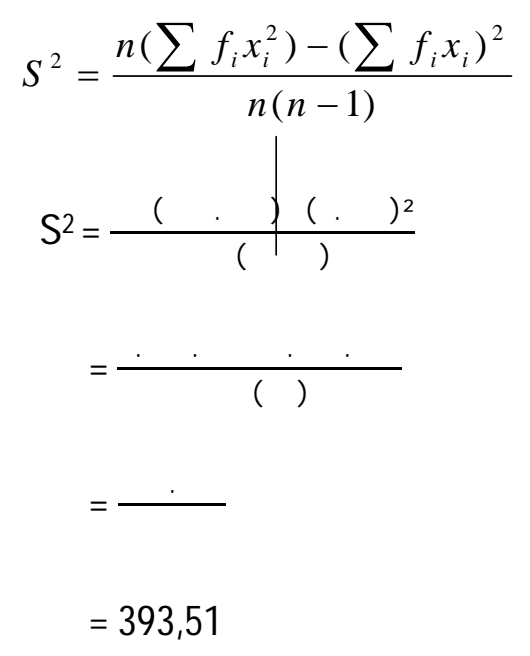

$S=\sqrt{ } 393,51=19,8$

h. Mencari Kemiringan Kurva(Km)

$$
\begin{aligned}
K m & =\frac{\bar{x}-M o}{S} \\
& =\frac{,}{,}
\end{aligned}
$$

$$
=+\cdot=-0,44
$$

Dari perhitungan diatas, diperoleh nilai $\mathrm{Km}$ sebesar $-0,44$, karena $\mathrm{Km}-0,44$ terletak antara (-1) dan (1), maka data diatas dikatakan terdistribusi normal.

\subsubsection{Analisis Data Posttest}

\section{Pembelajaran Tari Burung Bermain}

Hasil posttest yang diperoleh siswa dalam pembelajaran tari Burung Bermain sesudah diterapkan metode demonstrasi, dapat dilihat pada tabel distribusi frekuensi berikut ini:

TABEL DISTRIBUSI FREKUENSI POSTTEST

\begin{tabular}{|c|c|c|c|c|c|}
\hline Interval & $f_{\mathrm{i}}$ & $\mathrm{x}_{\mathrm{i}}$ & $\mathbf{x i}^{2}$ & $f_{\mathrm{i}} \mathbf{x}_{\mathrm{i}}$ & $\boldsymbol{f}_{\mathrm{i}} \mathbf{x}^{2}$ \\
\hline $75-77$ & 3 & 76 & 5776 & 228 & 17328 \\
\hline $78-80$ & 12 & 79 & 6241 & 948 & 74892 \\
\hline $81-83$ & 0 & 82 & 6724 & 0 & 0 \\
\hline $84-86$ & 10 & 85 & 7225 & 850 & 72250 \\
\hline $87-89$ & 0 & 88 & 7569 & 0 & 0 \\
\hline $90-92$ & 4 & 91 & 8281 & 364 & 33124 \\
\hline $93-95$ & 1 & 94 & 8836 & 94 & 8836 \\
\hline & 30 & 595 & 50652 & 2484 & 206430 \\
\hline
\end{tabular}

e. Mencari rata-rata nilai posttest $(\bar{X}$ )

$$
\bar{x}=\frac{\sum f_{i} x_{i}}{\sum f_{i}}
$$

$$
\begin{aligned}
& =2484 / 30 \\
& =82,8
\end{aligned}
$$


f. Mencari Modus nilai posttest (Mo)

$$
\begin{aligned}
& \left(b=78-0,5=77,5 ; P=3, ; b_{1}=12-3\right. \\
& \left.=9 ; b_{2}=12-0=12\right) \\
& M o=b+P(\longrightarrow) \\
& \text { Mo }=77,5+3(-) \\
& =77,5+3(-) \\
& =77,5+3(0,42) \\
& =77,5+1,26=78,76
\end{aligned}
$$

g. Mencari Simpangan Baku nilai posttest

$$
\begin{aligned}
S^{2} & =\frac{n\left(\sum f_{i} x_{i}^{2}\right)-\left(\sum f_{i} x_{i}\right)^{2}}{n(n-1)} \\
S^{2} & =\frac{(\quad)()^{2}}{(\quad)} \\
& =\frac{. \quad \cdot}{(\quad)} \\
& =.
\end{aligned}
$$

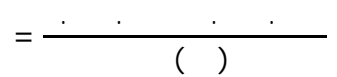$$
=26,02
$$$$
S=\sqrt{ } 26,02=5,1
$$

h. Mencari Kemiringan Kurva (Km)

$$
\begin{aligned}
K m & =\frac{\bar{x}-M o}{S} \\
& =\frac{,}{,} \\
& =\frac{,}{,}=0,79
\end{aligned}
$$

Dari perhitungan diatas, diperoleh nilai $\mathrm{Km}$ sebesar 0,79, karena $\mathrm{Km} \mathrm{0,79}$ terletak antara (-1) dan (1), maka data diatas dikatakan terdistribusi normal.

\subsubsection{Uji Hipotesis}

Setelah pengujian normalitas data, dimana data pretest dan data posttest telah terdistribusi normal, maka selanjutnya diadakan uji hipotesis uji $\mathrm{t}$ sebagai berikut :

$$
t=\frac{\overline{x_{1}}-\overline{x_{2}}}{\sqrt[s]{\frac{1}{n 1}+\frac{1}{n 2}}}
$$

\begin{tabular}{|c|c|}
\hline Pretest & Posttest \\
\hline $\mathrm{X}_{1}=55,6$ & $\mathrm{X}_{2}=82,8$ \\
\hline $\mathrm{S}_{1}{ }^{2}=393,51$ & $\mathrm{~S}_{2}{ }^{2}=26,02$ \\
\hline $\mathrm{S}_{1}=19,8$ & $\mathrm{~S}_{2}=5,1$ \\
\hline $\mathrm{n}_{1}=30$ & $\mathrm{n}_{2}=30$ \\
\hline & $\mathrm{S}=12,45$ \\
\hline
\end{tabular}




$$
\begin{aligned}
& t=\frac{\overline{x_{1}}-\overline{x_{2}}}{\sqrt[s]{\frac{1}{n_{1}}+\frac{1}{n_{2}}}} \\
& t=\frac{82,8-55,6}{\sqrt[12, \sqrt[45]{\frac{1}{30}-\frac{1}{30}}]{\sqrt[4]{0,03}}} \\
& t=\frac{27,2}{t=\frac{27,2}{12,45(0,17)}} \\
& t=\frac{27,2}{2,12} \\
& t=12,83
\end{aligned}
$$

Untuk mencari tabel untuk t (1-a) adalah :

$\mathrm{dk}=\mathrm{n}-1,=30-1,=29$

Berdasarkan perhitungan diatas telah diketahui thitungsebesar 12,83 dan tabel sebesar 2,045 setelah dikonsultasikan dengan data distribusi-t dengan taraf signifikan 0,05, maka dapat disimpulkan hipotesis bahwa ada pengaruh penggunaan metode demonstrasi dalam pembelajaran tari Burung Bermain, sesuai dengan kriteria pengujian hipotesis bahwa Ha diterima jika thitung $\geq t_{\text {tabel }}(12,83 \geq$ 2,045) berarti Ho ditolak.

\section{SIMPULAN}

Berdasarkan hasil penelitian maka dapat disimpulkan bahwa hasil nilai siswa dalam kegiatan ekstrakurikuler tari di SMP Negeri 36 Palembang menggunakan metode demonstrasi mampu memberi pengaruh terhadap peningkatan kemampuan siswa dalam menarikan tari Burung Bermain, hal ini dapat dilihat dari nilai rata-rata ekstrakurikuler tari setelah menerapkan metode demonstrasi (posttest) terhadap pembelajaran tari Burung Bermain sebesar 82,8 sedangkan nilai rata-rata sebelum menerapkan metode demonstrasi (pretest) terhadap pembelajaran tari Burung Bermain sebesar 55,6. Dengan demikian, metode demonstrasi dapat meningkatkan kemampuan siswa dalam menarikan tari Burung Bermain di SMP Negeri 36 Palembang. Berdasarkan pengujian Hipotesis didapat uji-t dengan hasil thitung 12,83 sedangkan tabel 2,045 dengan $d k=n-1=30-1=29$ sebesar 2,045. Hal ini berarti thitung $\geq t_{\text {tabel }}$ atau $12,83 \geq 2,045$. Sehingga dapat disimpulkan bahwa hipotesis 
yang menyatakan ada pengaruh yang Bermain dalam kegiatan ekstrakurikuler di SMP signifikan dalam penggunaan metode Negeri 36 Palembang diterima.

demonstrasi dalam pembelajaran tari Burung

\section{DAFTAR PUSTAKA}

Djamarah, Syaiful Bahri \& Aswan Zain. 2010. Strategi Belajar Mengajar. Jakarta: Rineka Cipta Kamila, Kartika. 2015. Kajian Seni Rupa Nusantara. Jakarta:Traju

Kementerian Pendidikan dan Kebudayaan Republik Indonesia. 2014. Seni Budaya. Jakarta: Pusat Kurikulum dan Perbukuan, Balitbang, Kemdikbud.

Martha, I Nengah. 2014. PengantarPendidikan. Yogyakarta: Graha IImu

Sudiarja.A . 2014. Pendidikan Dalam Tantangan Zaman. Yogyakarta: PT Kanisius

Sugiyono.2011. Metode Penelitian Kuantitatif Kualitatif dan R\&D. Bandung:Alfabeta 2011. Metode Penelitian Pendidikan. Bandung: Alfabeta

Syaefudin Sa'ud Udin. 2012. Inovasi Pendidikan. Bandung: Alfabeta

Wahyudiyanto. 2008. Pengetahuan Tari. Surakarta: ISI Press. 


\section{KETENTUAN PENULISAN ARTIKEL JURNAL SITAKARA}

1. Naskah berbahasa Indonesia bertemakan Seni Budaya yang meliputi hasil penelitian pengajaran seni budaya, cabang seni, dan kebudayaan.

2. Naskah harus asli dan belum pernah dimuat dalam media lain. Naskah dapat berupa hasil penelitian perorangan atau kelompok. Naskah ditulis dengan cara-cara yang sesuai dengan ketentuan penulisan artikel ilmiah menggunakan bahasa Indonesia yang baku, berupa ketikan, beserta soft line dalam CD-RW atau dengan mengirimkan email pada redaksi Jurnal Sitakara dengan alamat email: jurnalsitakarasendratasik@yahoo.com, spasi 1,5 jenis huruf Arrial Narrow ukuran 12, dengan panjang naskah antara 8-15 halaman pada kertas A4.

3. Artikel hasil penelitian memuat:

JUDUL

NAMA PENULIS

ABSTRAK

\section{A. PENDAHULUAN}

B. METODE PENELITIAN

C. HASIL DAN PEMBAHASAN

D. SIMPULAN

4. Artikel kajian konseptual memuat JUDUL

NAMA PENULIS

ABSTRAK

PENDAHULUAN

SUB JUDUL

SIMPULAN

DAFTAR PUSTAKA

\section{: XXX (HURUF KAPITAL)}

: (disertai jabatan dan institusi)

: (Bahasa Indonesia yang memuat 100- 150 kata diikuti kata kunci, dengan jenis huruf Arrial Narrow dan ukuran huruf 11 serta dicetak tebal).

: (Memuat latar belakang masalah, tinjauan pustaka Secara ringkas, masalah dan tujuan penelitian).

: (Berisi simpulan)

: XXX (HURUF KAPITAL)

: (disertai jabatan dan institusi)

: (Bahasa Indonesia yang memuat 100- 150 kata diikuti kata kunci, dengan jenis huruf Arrial Narrow dan ukuran huruf 11 serta dicetak miring)

: (Memuat latar belakang masalah, tinjauan pustaka secara ringkas, masalah penelitian dan tujuan penelitian)

: Sesuai dengan kebutuhan (tanpa numbering)

: (Berisi simpulan dan saran)

: (Berisi pustaka yang dirujuk dalam uraian naskah) 
5. Referensi sumber dalam teks artikel ditulis dengan menggunakan side note, contoh: (Jalalluddin, 1991:79); (Taufik, 2005;350); (Hamid dan Madjid, 2011:43). Sementara penulisan daftar pustaka disusun dengan ketentuan. Nama Pengarang. Tahun Terbit. Judul (dicetak miring). Kota Terbit: Nama Penerbit. Contoh: Koentjaraningrat. 2010. Manusia dan Kebudayaan Di Indonesia. Jakarta: Djambatan.

Daftar pustaka hanya memuat pustaka/sumber yang dirujuk dalam uraian dan disusun menurut abjad, tanpa nomor urut.

6. Naskah yang dimuat akan disunting kembali oleh redaksi tanpa mengubah isinya.

7. Naskah yang ditolak (tidak bisa dimuat) akan dikirim kembali ke penulis dengan pemberitahuan tertulis dari redaksi atau alamat email.

8. Penulis yang naskahnya dimuat akan mendapatkan 1 (satu) majalah nomor yang bersangkutan.

9. Contact Person: Treny (085357344704) dan Mainur (081373165553). 